\title{
Supply Chain Incentive Alignment: The Gap between Perceived Importance and Actual Practice
}

\author{
Andreas Norrman \\ Department of Industrial Management and Logistics \\ Lund University, SE-221 00 Lund, Sweden \\ Email: andreas.norrman@tlog.lth.se (Corresponding Author) \\ Dag Naslund \\ Department of Industrial Management and Logistics \\ Lund University, SE-221 00 Lund, Sweden \\ Department of Management \\ Coggin College of Business, University of North Florida, USA \\ Email: dag.naslund@tlog.lth.se
}

\begin{abstract}
Incentive alignment is discussed as one of the key factors for successful implementation of supply chain management. However, there is a lack of empirical research regarding implementation as well as evaluation of the effects of alignment mechanisms in practice. The purpose of this study is therefore to explore and describe the current practice and to identify gaps of Supply chain incentive alignment. The study is an explorative and descriptive survey study based on forty-eight responses from members, supply chain officers, of the Swedish Supply chain panel. The theoretical lenses are based on literature discussing incentive alignment in supply chains, e.g. principalagency theory and supply chain contracting, but also on literature discussing internal process based management and rewards for goal congruence. The study shows a clear gap between perceived importance and realized practice of both external (inter-organizational) and internal (cross-functional) incentive alignment. Very few of the existing sophisticated coordinating mechanisms proposed in theory were used to any significant extent. In fact, the internal incentive structures seem to counter act, and not support, supply chain orientation. This finding relates not only to non-logistics departments but also to functions in "the logistics family". The major challenge, both externally and internally, is to be able to define incentives that drives behavior in the right direction. The study clearly shows gaps between practitioners' intent and current practice, and it provides a broad range of more sophisticated and coordinating mechanisms than the ones mainly used today.
\end{abstract}

Keywords: incentive alignment, goal congruence, cross functional, group incentives, supply chain integration, silo thinking

\section{INTRODUCTION}

Even though Supply Chain Management (SCM) and related topics, such as SC integration and SC collaboration, have been discussed since the 1980s as ways to improve performance and profitability, few articles provide empirical evidence of their successful implementation (Stevens, 1989; Narayanan and Raman, 2004; Naslund and Hulthen, 2012; Stevens and Johnson, 2016; Porter, 2019). Managers discuss collaboration and integration much more than they actually practice them (Bowersox et al., 2000; Bagchi and SkjoettLarsen, 2003). A major challenge in SC integration is that it involves both integrating processes among key members of the SC (external integration), as well as integrating crossfunctional business processes (internal integration) within the firm (e.g., Ellinger, 2000; Pagall, 2004; Simatupang and Sridharan, 2005; Lambert et al., 2005; Trkman et al., 2007; Fawcett et al., 2008; Grubic et al., 2010; Richey et al., 2010; Cook et al., 2011; Schoenherr and Swink, 2012; Msimangira \& Venkatraman, 2014; Enz and Lambert, 2015; Fawcett et al., 2015; Ralston et al., 2015). External integration relates to the extent to which companies establish collaborative relationships, share information, and coordinate external integration activities with both suppliers and customers (Narasimhan and Kim, 2001; Gunasekaran, 2004). Internal integration is the extent to which business functions work cooperatively and interact through cross-functional process integration to resolve conflicts and achieve mutual goals (Pagell, 2004; Danese et al., 2013; deSouza and Haddud, 2017). Theoretically, integration that extends beyond functional silos and firm boundaries should provide value for customers in terms of higher quality, enhanced service level, and lower costs (Ralston et al., 2015; Wong et al., 2011).

A fundamental aspect of successful external and internal integration is that different organizational subunits should work in the same direction - their incentives aligned, and their functional goals are congruent. Risk and reward sharing are argued by many authors as the key factors for the successful implementation of SC management (e.g., Cooper et al., 1993; Cooper et al., 1997; Motwani et al., 1998; Bowersox et al., 2000; Mentzer et al., 2001; Lee, 2004; Fawcett et al., 2008). Other researchers describe this phenomenon as supply chain incentive alignment (e.g., Bagchi and Skjoett-Larsen, 2003; Agrell et al., 2004; Lee, 2004; Narayanan and Raman, 2004; Simatupang and Sridharan, 2005, 2008; Fugate et al., 2006; Norrman, 2008; Lundin and Norrman, 2010). Supply chain incentive alignment is argued to be one of the key antidotes for the successful implementation of SCM and external integration; misaligned incentives often cause excess inventory, stockouts, incorrect forecasts, inadequate sales efforts, and even poor customer service (Narayanan and Raman, 2004). For internal integration, incentives, such as internal 
organizational evaluation, and a mutual reward system are often used to improve alignment (Ellinger, 2000; Pagell 2004; Fawcett et al., 2015). Improving alignment can reduce the problems caused by the functional silo phenomenon, leading to increased integration and cross-functional collaboration. In turn, this could lead to enhanced company and SC performance.

However, what is the current practice in terms of the implementation of ideas and antidotes for external and internal integration a decade after these concepts have been highlighted in SCM research? Do gaps still exist between the perceived importance and actual practice of supply chain incentive alignment? The purpose of this study is to explore and describe the current practice and gaps in supply chain incentive alignment. In the following section, we discuss related literature. We then present the methodology and results of our study. Finally, we discuss our conclusions, as well as avenues for future research.

\section{THEORETICAL LENSES}

\subsection{External Integration, Supply Chain Incentive Alignment, and Contract Mechanisms}

One problem with risk and reward sharing in SCs is that companies might prioritize their own interest instead of the entire SC's, despite the fundamental vision of SCM that companies should focus on the SC as a whole (Agrell et al., 2004). SC members are torn between making decisions based on a local (organizational) perspective vis-a'-vis a global (SC) one. Measurements and incentives make companies prioritize organizational goals instead of the channel goal (Simatupang and Sridharan, 2005). A lack of aligned incentives is one of the factors that create SC discontent (Simatupang and Sridharan, 2005). In a large empirical study, Narayanan and Raman (2004) find that companies did not act in ways that maximized the network's profit. Consequently, the SCs performed poorly. They (p. 94) argue that "a supply chain stays tight only if every company in it has reasons to pull in the same direction."

Narayanan and Raman (2004) recommend three types of solutions to redesign incentives: contract-based (changing contracts to reward partners for acting in the SC's best interest), information-based (gathering or sharing information that was previously hidden), and trust-based solutions (using intermediaries or personal relationships to develop trust with SC partners) (see e.g., Fawcett et al., 2017). Simatupang and Sridharan (2005) recommend antidotes, such as mutual objectives, appropriate measures, information sharing, decision synchronization, incentive alignment, and streamlined processes. Narayanan and Raman (2004) argue that companies should explore contractbased solutions before they use other approaches, as contracts are quick and easy to implement. Monetary incentives could be developed or modified to induce SC partners to behave in ways that are best for everybody. Bowersox et al. (2000) also propose that financial linkages should be created to make firms dependent on mutual performance, and encourage risk and benefit sharing by detailing how rewards and penalties are to be appropriated across partner firms. Risks, costs, and rewards of doing business should be distributed fairly, but managers find it tedious and time consuming to define roles, responsibilities, and accountability for businesses that they do not manage directly (Narayanan and Raman, 2004).

Several researchers in the operations research stream of literature suggest the use of contracts to solve misalignment problems (e.g., Lee and Whang, 1999; Cachon, 2002; Agrell et al., 2002). Different contract mechanisms are modeled to gain insights into how contracts could affect incentives for coordination and different performance measures (Tsay et al., 1998; Cachon, 2003; Leng and Zhu, 2009; and Hezarkhani and Kubiak, 2010; Eng-Larsson and Norrman, 2014). Tsay et al. (1998) classify SC modelling literature focused on contracts into eight streams based on different contract clauses, such as pricing, minimum purchase commitment, quantity flexibility, and lead times. In this literature, the least sophisticated contract mechanism (and the most commonly used one in practice) is wholesale price, which means that the buyer simply pays a fixed price per unit (Tsay, 1999; Anupindi and Bassok, 1999; Lariviere and Porteus, 2001). Because of its simplicity, this contract mechanism does not provide significant incentives for more advanced coordination. Another common contract mechanism, also without a significant incentive to improve SC coordination, is to give volume discounts. In fact, Lee et al. (1997) discuss how promotions discount could create bullwhip effects. Agrell et al. (2004) compare the traditional cost-plus contract for outsourcing services in the telecom industry with other types of contract mechanisms and find that it does not provide relevant coordination incentives. However, Cachon (2003) is convinced that SC performance can improve if firms coordinate by contracting on a set of transfer payments such that each firm's objective is aligned with that of the SC. Examples of payment types are quantity flexibility agreements (Tsay, 1999; Nandi, 2016) and the revenue-sharing scheme (Cachon and Lariviere, 2005; Dana and Spier, 2001). Dana and Spier (2001) show empirical evidence of how a successful revenue-sharing contract contributed to the increased availability of and higher profit for all members of an SC. Other ways to incentivize partners are to use penalties and bonuses (sticks and carrots), preferably defined in service level agreements (Liang and Atkins, 2013).

Researchers using a more qualitative approach (e.g., Brun and Moretto, 2012; Cooper and Ellram, 1993) also present sophisticated mechanisms for sharing risk and rewards in an SC. Cooper and Ellram suggest that alignment can be achieved in three ways: cross-owning equity, incentive schemes and investments in joint assets. The sharing of risks and rewards is common in certain Japanese industries, in which companies cross-own equity interests in one another. Thus, if one company does well, all companies benefit directly because they are financially tied beyond the bounds of an ordinary business relationship. Cusumano and Takeishi (1991) describe another feature of Japanese contracting and pricing practices: semi-annual price reduction throughout the model life cycle. This practice is based on the idea that suppliers should be able to reduce their costs through experience and continual efforts to improve product design, materials, and manufacturing methods. Norrman (2008) shows other empirical examples from the high-tech industry using more advanced structured agreements, such as minimum purchasing commitment, but he also discusses how forecast accuracy and cost for excess/obsolete materials are important issues to address and 
align. In more advanced collaboration types, such as $V M I$ and CPFR (e.g., Barratt, 2004), some examples of contractual issues to consider are who takes ownership of the inventory and who manages it. Obviously, various combinations distribute risk and responsibilities differently (Ståhl Elvander et al., 2007).

Principal agency theory is another theoretical lens that has the contract as the unit of analysis (e.g., Jensen et al., 1976; Eisenhardt, 1989). This theory has clearly inspired researchers, such as Simatupang and Sridharan (2005) and Narayanan and Raman (2004), to highlight incentive alignment issues, such as hidden action, hidden information, and badly designed contracts. In principal agency theory, the optimal choice of contract type depends on the information available and on the uncertainty structure of the situation, the risk attitudes of the actors, the alignment of the actors' objectives, and the cost of monitoring and enforcement of the contract. For choosing contract type, Rapp and Torstensson (1994) highlight (Figure 1) the two dimensions of a) whether there are relevant and measurable result variables and b) whether there is low uncertainty in terms of how activities are performed. Based on these dimensions, the behaviorbased contract type (e.g., normal salary) or the outcomebased contract type (bonus linked to performance) could be chosen. Following principal agency theory also, performance-based contracting (see e.g., Selviaridis and Norrman, 2015) has been increasingly discussed in research and practice, especially in industries in which service is of growing importance. Coordination toward joint SC goals could increase by focusing on performance and outcome. However, behavior-based or outcome-based contracts are not appropriate when the relevant result variables for measuring the outcome do not exist, or when activities/behavior cannot be clearly monitored and connected to the results. This kind of uncertainty (in which it is both difficult to measure outcome and to monitor activities) exists in long global SCs, in which components and systems interrelate with one another, and pinpointing the causes of certain problems or how they can be measured is difficult (e.g., corporate social responsibility [CSR] issues).

Rapp and Torstensson (1994), based on Ouchi (1979), propose more sophisticated mechanisms, such as social control or group incentives. These mechanisms mean that an individual agent is paid based on the outcome of a group of agents, and this group of agents themselves is allowed to monitor one another and select whom they trust to include as group members (social control). Thus, the principal incentivizes or penalizes the entire group.

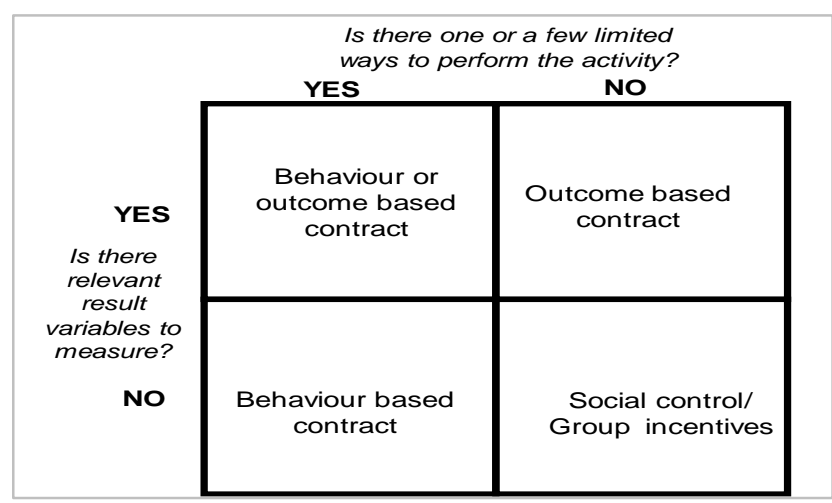

Figure 1 Different contract types fitting different situations Source: Based on Rapp \& Torstensson, 1994, p. 17
Van Hoek and Weken (2000) describe the original setup for smart cars in which group incentives were used. The suppliers were not paid until the core coordinating company was able to test the final car's quality and could sell it to customers. A supplier was not paid for any individual component if it did not meet the quality inspection and was assembled, and no supplier was paid until the entire car had the passed the final quality inspection. Examples of the contract mechanisms discussed above are summarized in Table 1.

Table 1 Examples of contract mechanisms discussed in supply chain literature

\begin{tabular}{|c|c|}
\hline $\begin{array}{l}\text { Example of contract } \\
\text { mechanisms }\end{array}$ & Examples of references \\
\hline $\begin{array}{l}\text { Wholesale price, cost } \\
\text { per unit }\end{array}$ & $\begin{array}{l}\text { Tsay et al. (1998), Anupindi and } \\
\text { Bassok (1999), Lariviere and Porteus } \\
\text { (2001) }\end{array}$ \\
\hline Volume discount & Tsay et al. (1998) \\
\hline Promotions discounts & Lee et al. (1997) \\
\hline $\begin{array}{l}\text { Price based on cost- } \\
\text { plus }\end{array}$ & Agrell et al. (2004), Norrman (2008) \\
\hline $\begin{array}{l}\text { Price reduction over } \\
\text { time }\end{array}$ & Cusumano and Takeishi (1991) \\
\hline Revenue sharing & $\begin{array}{l}\text { Dana and Spier (2001), Cachon and } \\
\text { Laviere (2005) }\end{array}$ \\
\hline $\begin{array}{l}\text { Performance-based } \\
\text { contracting }\end{array}$ & $\begin{array}{l}\text { Liang and Atkins (2013), Selviaridis } \\
\text { and Norrman (2015) }\end{array}$ \\
\hline $\begin{array}{l}\text { Supplier paid when the } \\
\text { final product is sold }\end{array}$ & van Hoek and Weken (2000) \\
\hline Quality-based payment & van Hoek and Weken (2000) \\
\hline Other group incentives & Torstensson and Rapp (1994) \\
\hline Direct investments & $\begin{array}{l}\text { Cooper and Ellram (1993), Fawcett et } \\
\text { al. (2008) }\end{array}$ \\
\hline $\begin{array}{l}\text { Minimum purchasing } \\
\text { commitment }\end{array}$ & Tsay et al. (1998), Norrman (2008) \\
\hline Forecast accuracy & Norrman (2008) \\
\hline $\begin{array}{l}\text { Penalties or bonus for } \\
\text { bad delivery service }\end{array}$ & Liang and Atkins (2013) \\
\hline $\begin{array}{l}\text { Cost for } \\
\text { excess/obsolete } \\
\text { material }\end{array}$ & Norrman (2008) \\
\hline $\begin{array}{l}\text { Risk/gain sharing } \\
\text { contracts }\end{array}$ & $\begin{array}{l}\text { Dana and Spier (2001), Cachon et al. } \\
(2001)\end{array}$ \\
\hline $\begin{array}{l}\text { VMl suppliers' own } \\
\text { stock }\end{array}$ & $\begin{array}{l}\text { Barratt (2004), Ståhl Elvander et al. } \\
(2007)\end{array}$ \\
\hline Consignment stock & Ståhl Elvander et al. (2007) \\
\hline
\end{tabular}

\subsection{Internal Integration and Rewards for Goal Congruence}

The alignment of functions, such as sales, marketing, and operations, is advocated to serve customers in a way that ensures product availability at the least cost and asset investments; in turn, this helps achieve successful internal integration (Stank et al., 2011). However, cross-functional integration and collaboration are poorly understood and markedly rare (Ellinger et al., 2006). Van Hoek et al. (2008) argue that research about aligning logistics with peer internal functions is limited. The general lack of a cross-functional, process-oriented approach has been discussed for a long time in research with labels, such as silo thinking (Rummler and Brache, 1991; Stevens, 1989; Spekman et al., 1998; Ellinger, 
2000; Barratt, 2004; Gimenez and Ventura, 2005; van Hoek and Mitchell, 2006; Ellinger et al., 2006; Fawcett et al., 2008; Richey et al., 2010; Fawcett et al., 2015; Hulthen et al., 2017), turf protection (Ellinger, 2000; Fawcett et al., 2008; Fawcett et al., 2015), pockets of power (Bowersox et al., 2000), the Great Divide (Bowersox et al., 2000; Richey et al., 2010), and territories (Fawcett et al., 2015). Still, many researchers point out that internal cross-functional integration is difficult to implement in practice (e.g., Cook et al., 2011; Ralston et al., 2015; Fawcett et al., 2015). One problem is the traditional organizational structure, which results in different ways of thinking and divergent values of the functional areas (Stank et al., 2011; Piercy and Ellinger, 2015). Even though Shapiro (1977) discussed the problems caused by different cultures, personalities, goals, and rewards in various functions over 40 years ago, these problems seemed equally relevant and significant today.

Conflicting goals, divided into different incongruent functional objectives, result in functions pulling in different directions; as a result, these goals act as inhibitors of collaborative behavior (Ellinger et al., 2006). Discussing strategic misalignment, such as goal incongruence and misaligned metrics, Fawcett et al. (2015) agree with this assertion. Performance measurements tend to reward functional behaviors and are often in conflict across functions (Enz and Lambert, 2015). Therefore, they emphasize the importance of measuring the financial outcomes of cross-functional initiatives. Similarly, Barratt (2004) recommends common goals and objectives. Ellinger et al. (2006) propose joint accountability for outcomes, such as by giving mutual rewards for success and mutual responsibility for expectations to facilitate collaborative behavior.

Other researchers argue that internal integration is difficult, as it requires changes in organizational structure and changes in incentive systems (Bowersox et al., 2000; Gimenez and Ventura, 2005; Richey et al., 2010). Ellinger et al. (2000), as well as van Hoek and Mitchell (2006), argue that one example of what firms should do to promote integration is to improve the reward system. Ellinger (2000) explicitly focuses on a mechanism called organizational evaluation and reward system. Other authors who stress the importance of incentives for internal integration are van Hoek and Mitchell (2006), van Hoek et al. (2008), and Stank et al. (2001).

The major takeaway from this research stream is that different functional goals should be aligned and rewards (incentives) for goal congruence should exist to achieve cross-functional internal integration.

\subsection{Interrelation of External and Internal Integration}

External and internal integration influence each other (Gimenez and Ventura, 2005), but there are various views on the relationship between these two. Some researchers argue that internal integration should precede external integration, as it can have a positive effect on the business performance of individual firms within an SC in terms of enhanced product/service offerings, growth, and profitability (Stevens, 1989; Croxton et al., 2001). However, other authors believe that external integration, demonstrated by interaction with suppliers and customers, can stimulate internal integration
(Halldórsson et al., 2008; Rodrigues et al., 2004). Another approach, as suggested by Richey et al. (2010) and Gimenez and Ventura (2005), is that organizations should focus simultaneously on external and internal integration, as they are interlinked. This view corresponds with that of Stank et al. (2001) in that the firms with the best practices work simultaneously with external and internal integration. Finally, Hoek and Mitchell (2006) ask why the focus is on external integration when companies are not aligned internally: should one learn how to crawl before learning how to walk? Van Hoek and Mitchell argue that internal misalignment can explain why SC efforts often do not fully deliver or even fail.

Despite numerous suggestions regarding supply chain incentive alignment during the last decade, both related to external and internal integration, empirical research on this topic is lacking. The literature has proposed several different mechanisms (Table 1) to improve external integration through incentive alignment, with the lack of internal goal congruence being stressed as a key issue for cross-functional internal integration. However, to our knowledge, little research has empirically examined the degree to which different mechanisms are implemented in practice. Research is lacking both in terms of practitioners' perceptions of incentive alignment and detailed knowledge of implementation in practice. Our goal is to understand the degree to which different proposed aligning mechanisms are used and to identify potential major gaps that need to be addressed.

\section{METHOD}

This study is of an explorative and descriptive nature. For this kind of study, Forza (2002) recommends collecting data through an exploratory survey with experts in the field. Furthermore, the exploratory survey is a commonly method used in SC and operations management research (e.g., Hubner et al., 2016). An exploratory survey is appropriate for discovering new facets of the phenomenon under study and can provide a basis for more in-depth survey research. It can also help uncover or provide preliminary evidence of association among concepts.

\subsection{Construction of The Survey}

The survey explored different aspects of supply chain incentive alignment, with a specific focus on the mechanisms for external integration, as described in the literature. The survey investigated the degree to which different mechanisms were used, both upstream and downstream in the SC. Questions regarding goal congruence for internal cross-functional integration were added to understand the level of internal incentives in order to reduce the functional silo problem. The survey was initially reviewed by one academic and one practitioner to evaluate the appropriateness and functionality of the questions (Forza, 2002). Feedback was used to modify the survey instrument. The main questions of the survey focused on the following issues:

- How important is incentive alignment between different important partners in your SC? How well developed is your company in this area? 
- To what degree does your company use different contract mechanisms for important products you buy (or important suppliers)?

- To what degree does your company use different contract mechanisms for important products you sell (or important customers)?

- How important is the internal alignment of different functions' incentives (bonuses, key performance indicators for promotions, etc.) to improve your company's SC performance? How well developed is your company in this area?

- To what degree do the different functions/departments in your company have an incentive structure that supports (not counteracts) your SCM work?

- Which are the three main challenges you face in relation to supply chain incentive alignment?

Respondents were asked to answer these questions on a seven-point Likert scale (with $1=$ not important/to a low extent and $7=$ very important/to a high extent).

\subsection{Data Collection and Sample}

This study was a part of a larger panel study with a Swedish supply chain panel. This panel was created by inviting managers in large Swedish manufacturing and retail companies to participate in a series of explorative and descriptive web surveys. The officers were identified through their membership in logistics professional organizations, through Internet sources, and via personal networks. A criterion for membership in the panel firms was that the respondent should be a high-level senior officer in the field of logistics or SC management. Consultants, logistics service providers, or non-profit organizations were excluded. In total, 70 companies and respondents originally signed up for the panel. An advantage of the panel was that unlike traditional random surveys, all respondents agreed to answer the study, and they were all experts with significant theoretical and/or practical experience in the area. Over the years that the panel worked, the respondents sometimes changed job or position, or they were on leave - something that could not always be tracked by the software tool used for distributing the questionnaires and collecting answers. Thus, the actual number of respondents varied between surveys. In total, six different web survey studies were conducted with the panel. The surveys explored and described the current status of important SC issues, such as SC strategy, SC measurement, SC decision synchronization (with a focus on S\&OP), supply chain incentive alignment, SC information sharing, and SC risk management.

This study on supply chain incentive alignment was the fourth one we conducted. Forty-eight of the panel's 70 members answered this survey, which was equivalent to a response rate of $68.6 \%$. A total of three reminders were sent out. To assess non-response bias, we compared early versus later respondents (Armstrong and Overton, 1977). The first 15 respondents who answered within four days were classified as early respondents, whereas the last nine respondents who answered after one month were classified as late respondents. The results from the t-tests revealed no significant difference among the answers in the survey between the two groups. Therefore, it seems that nonresponse bias does not pose a significant problem for this study.

\section{RESULTS \\ 4.1 Importance and Status of Incentive Alignment}

The panel members indicated that incentive alignment is important, both internally and from an SC perspective. However, their responses also showed that the companies are not very developed in terms of addressing incentive alignment (Figure 2). On a seven-point Likert scale (with $1=$ not important/to a low extent and 7=very important/to a high extent), the mean of importance for supply chain incentive alignment was 4.43 (standard deviation [std]: 1.41), whereas the mean of the company's current status was only 2.72 (std: 1.48). A paired t-test was used to compare importance versus the company's own status of incentive alignments. This indicates statistical significance at $\mathrm{p}<0.001$ (two-tailed test). The companies also stated that in cases in which they have actively designed an incentive structure, it is with the first tier. While $56 \%$ have not actively designed incentives, $28 \%$ have done it with first-tier suppliers, $24 \%$ with transport providers, and $14 \%$ with first-tier customers. No company has designed incentives related to second-tier suppliers or customers.

Regarding internal integration, the overall result was similar. While it was considered to be important (mean: 4.73, std: 1.38), the degree of implementation was low (mean: 3.02, std: 1.31). The t-test for internal integration also indicated strong statistical significance between perceived importance and the companies own status.

\subsection{Interorganizational Incentive Alignment- Upstream}

We likewise investigated the degree to which different contract mechanisms were used by the companies to incentivize alignment between themselves and their important suppliers (selling important products). As most companies differentiate relationships, the purpose was to focus on important relationships in which the probability for more sophisticated mechanisms (giving incentives for coordination) should be higher. The results clearly show (Figure 3) that the use of more sophisticated mechanisms is very limited. The dominant mechanism, even in the context of important suppliers/products, is the traditional and simple mechanism of price per unit (wholesale price). A statistical comparison (t-test) between the use of price per unit and all other mechanisms (see Appendix) shows that price per unit (wholesale price) is more significantly used than the other surveyed mechanisms (see the Appendix).

A similar comparison between volume discount and all other surveyed mechanisms shows that it is also more significantly used than all the other mechanisms, except for two (see the Appendix). One mechanism that seems to be slightly more used by some panel members and not significantly less used than volume discount is minimum purchase commitment. It is clearly a more sophisticated mechanism that could drive behavior in a more risk/rewardsharing mode. 
Two other mechanisms, promotions and cost-plus, are significantly less used than volume discount, although they are used to a high degree by certain respondents. It should be noted that some studies argue that these mechanisms drive $\mathrm{SC}$ behavior in a direction that, in many cases, is counterproductive from an SCM perspective (e.g., creating bullwhip effects or increasing cost). Another observation is that negatively oriented penalties (e.g., for poor delivery accuracy, lead time, or quality) seem to be used to a higher degree than bonuses if suppliers perform well. This indicates that companies prefer using sticks more than carrots to incentivize their suppliers. Group incentives are hardly used at all. Sales-based payment, in which suppliers are paid first when the final products are sold, is almost never used. (An exception was respondents getting it from their customers.) Quality-oriented group incentives, in which suppliers are not paid until the quality of the final product is confirmed, are slightly more popular. While a limited number of companies use this mechanism to a very high degree, most companies do not use it at all.

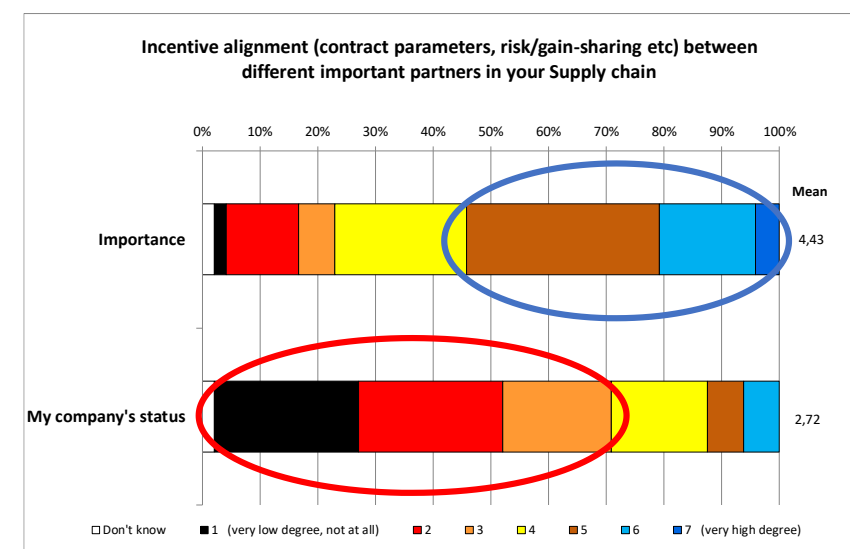

Mean of Importance 4.43 (std 1.41), Mean Current status 2, 72 (std 1,48).

t-test: statistical significance (p-value) at 0.000 ->

significant difference at $p<0.001$ (two-tailed test).

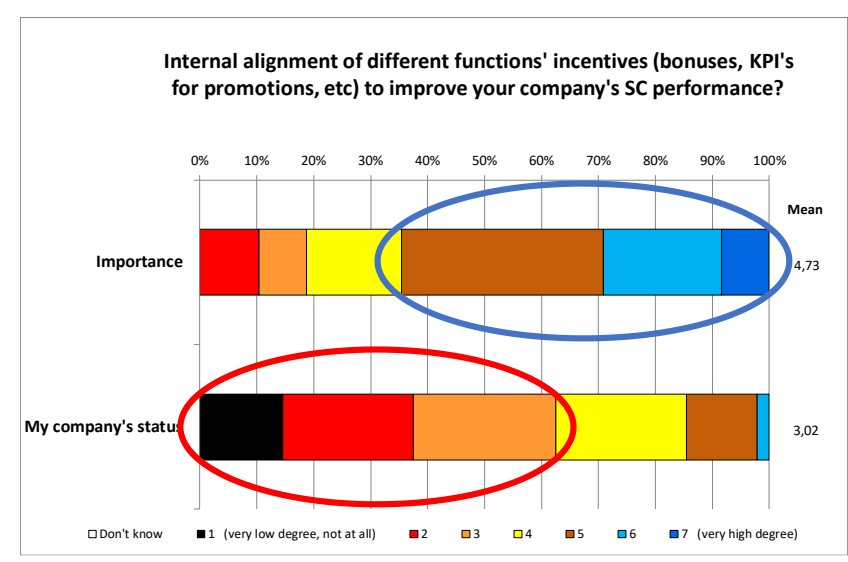

Mean of Importance 4.73 (std 1.38), Mean Current status 3,02 (std 1,31).

t-test: statistical significance (p-value) at 0.000 ->

significant difference at $p<0.001$ (two-tailed test).

Figure 2 Importance versus current status of supply chain incentive alignment and internal alignmnent.

\section{To what degree does your company use different contract mechanisms for importants products you buy (or important suppliers)?}

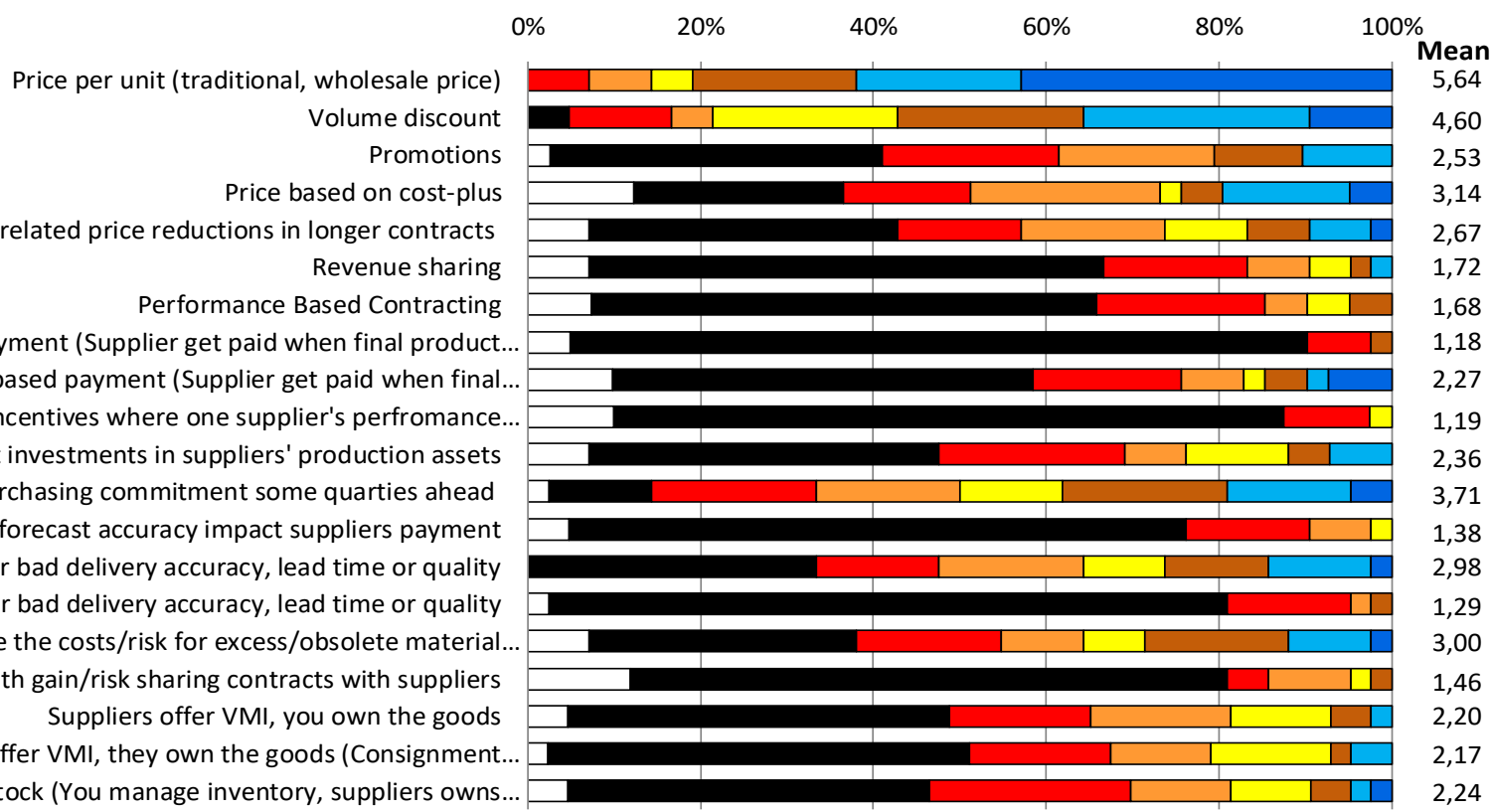

$\square$ Don't know $\square 1$ (very low degree, not at all) $\square 2 \quad \square 3 \quad \square 4 \quad \square 5 \quad \square 6 \quad \square 7$ (very high degree)

Figure 3 Use of different contract mechanims with important suppliers 


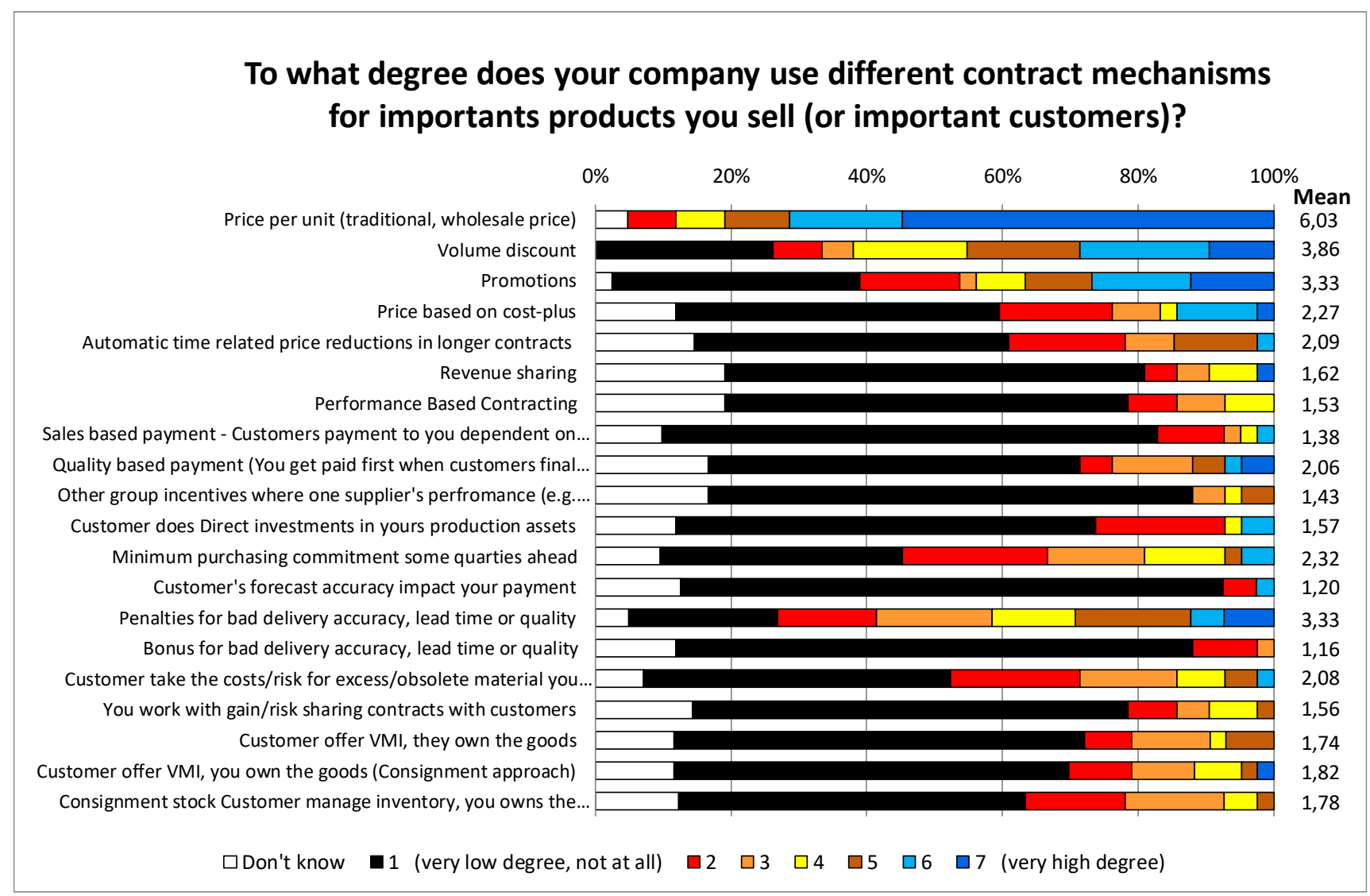

Figure 4 Use of different contract mechanims with important customers.

\subsection{Interorganizational Incentive Alignment- Downstream}

We also investigated the degree to which different contract mechanisms were used by the companies to incentivize alignment with their important customers. As relationships are normally differentiated, the purpose was to focus on the most important relationships in which the probability for the use of more sophisticated mechanisms (giving incentives for coordination) should be higher.

The low implementation of sophisticated mechanisms to incentivize alignment in SCs downstream is evident in the collaboration upstream with important customers (Figure 4).

In fact, the pattern seems even stronger, meaning that coordination is lower and sophisticated mechanisms are used to an even lesser degree. For many aspects, the number of uncertain respondents (don't know) is also higher, which in itself could indicate that the respondents have lower awareness of the commercial interfaces with customers than with suppliers.

The traditional and simple mechanism of (wholesale) price per unit is even more commonly used upstream than downstream. While volume discount is also common, it is less commonly used with customers than upstream with suppliers. On the other hand, promotions seem to be used more frequently. Penalties are also quite commonly used. However, only a small number of respondents utilize mechanisms designed for risk and reward sharing to a high degree. The number of respondents implementing these to a low degree is even higher. Examples of incentive mechanisms in which risk and reward sharing can be found are minimum purchase commitment and customers' accountability for bad forecasts.

\subsection{Internal Cross-Functional Incentive Alignment}

The results on the degree to which different departments were using incentive structures to support and not counteract SCM were disappointing. Surprisingly enough, not even traditional logistics family departments, such as transportation, purchasing, warehousing, and logistics/SCM, seem to have a strong average use of reward systems promoting SCM and driving goal congruence (Figure 5). In fact, the companies seem to be divided into two groups: those that have counteracting structures and those that have supporting structures. For surprisingly many, these departments also used reward structures with incongruent functional objectives that were counteracting the more holistic approach.

Similarly, other important functions for SCM, such as sales, marketing, finance, product development, and $\mathrm{R} \& \mathrm{D}$, were perceived to mainly have goals and incentives that conflict with SCM. Very few SC executives found internal incentives that are supportive of SCM in these functions. We also note that quite many respondents (working as senior logisticians/SCM in leading positions) did not know much about other functions' incentive systems, which in itself is proof of the limited cross-functional knowledge in this area. This lack of mechanisms and rewards for driving goal congruence and cross-functional integration, in turn driving the opposite behavior, indicates that companies have forgotten the important aspect of implementing measures to reduce silo thinking. 


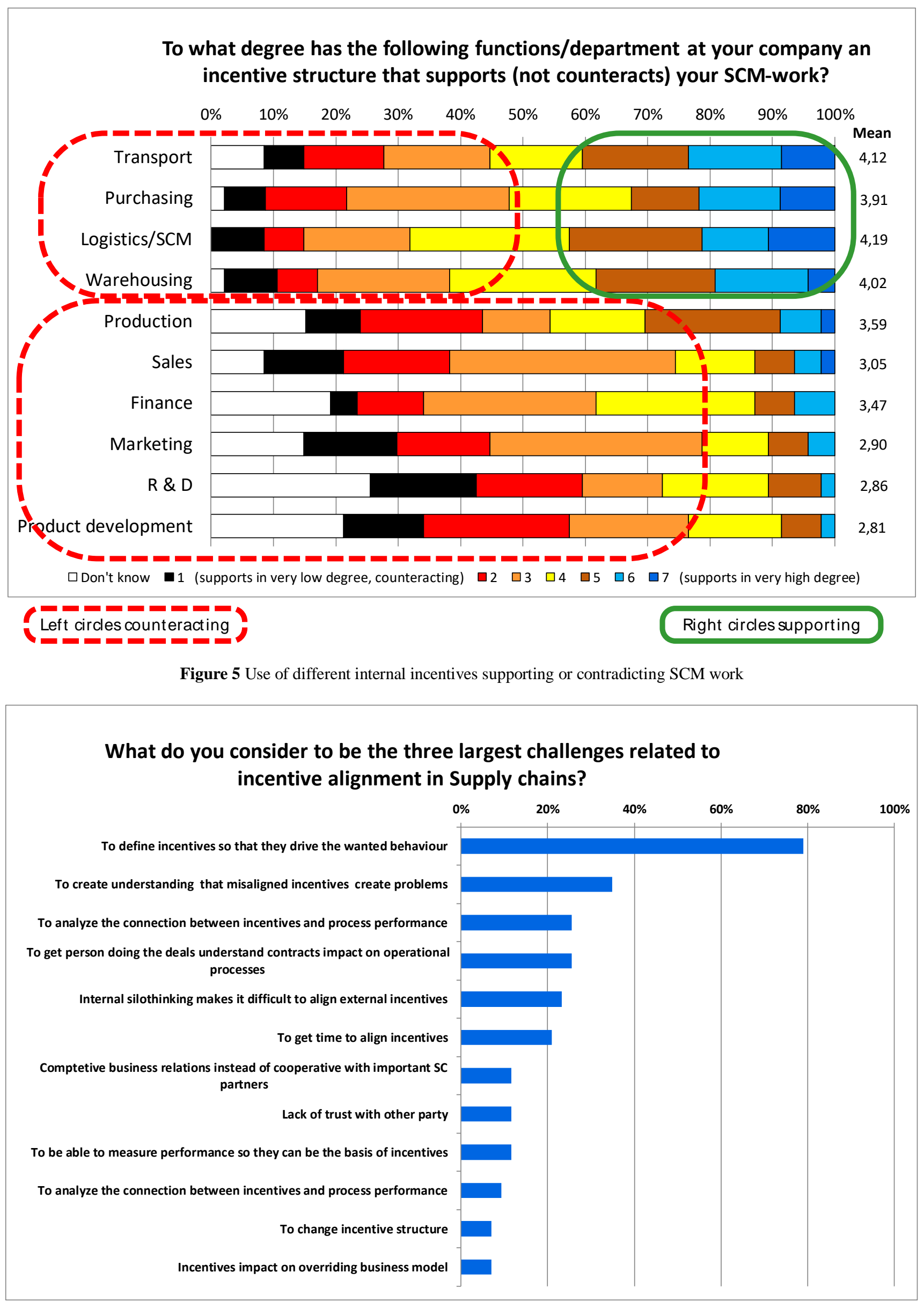

Figure 6 Twelve major challenges related to supply chain incentive alignment 


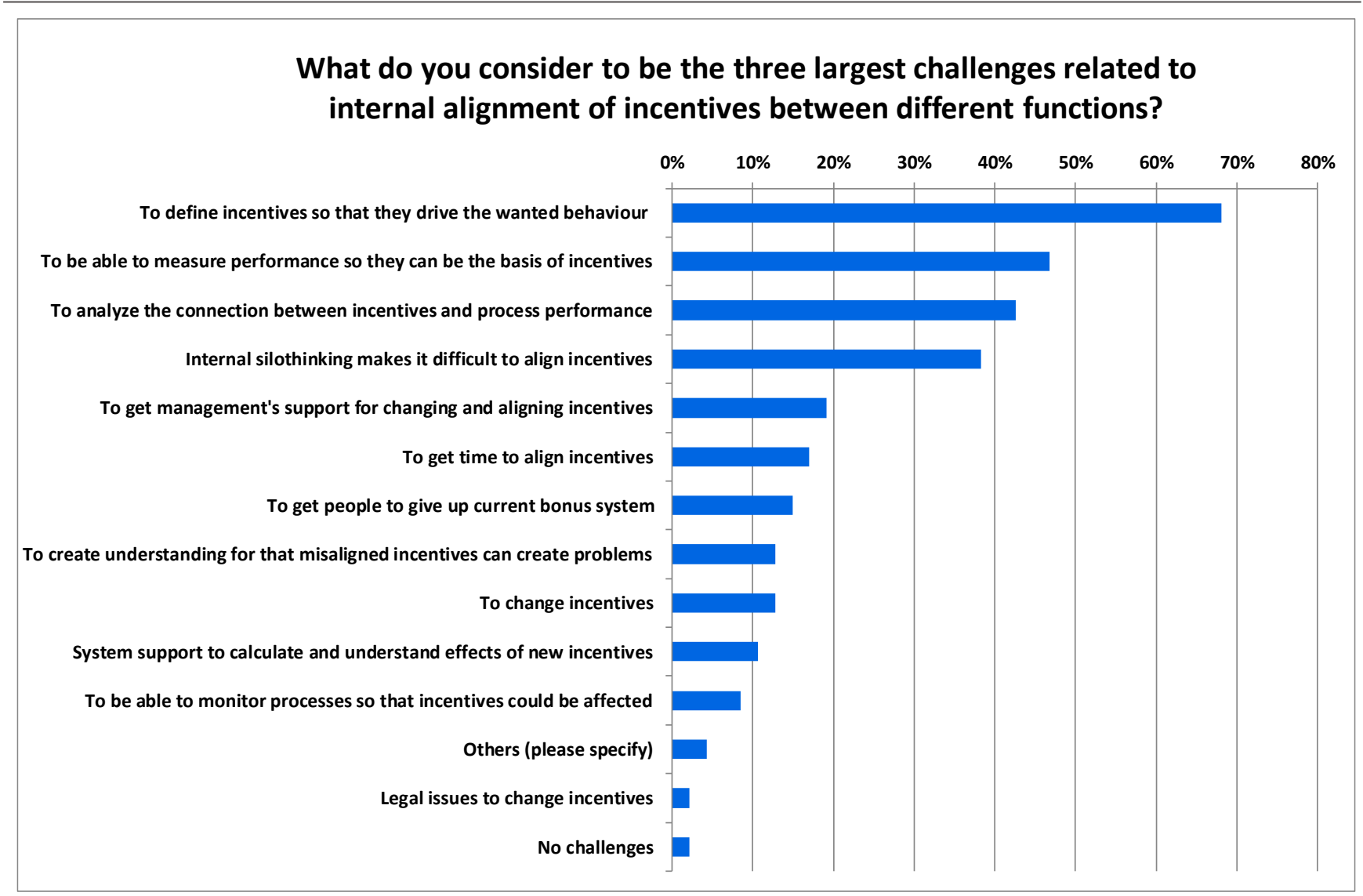

Figure 7 Major challenges related to internal incentive alignment

\subsection{Challenges}

To understand how the gaps can be bridged, the respondents were asked to identify the three main challenges (out of 21) in aligning incentives in the SC (Figure 6) and achieving internal incentive alignment (Figure 7). The most important challenge in both areas is how to define incentives so that they will drive the desired behavior. In the interorganizational context, almost $80 \%$ ranked this among their top three challenges. The second most important challenge was to create the understanding that missing incentive alignment could create problems, especially among employees involved in negotiating and contracting. The respondents indicated that those employees making the deals did not fully understand the impact of the different contract mechanisms on operational processes. Other common problems were to understand the connection between incentives and performance and to allocate time for incentive alignment. Interestingly enough, the fifth most important challenge was the internal silo thinking, which supports the theoretical discussion that external integration is dependent on internal integration.

Similar to the case for SC alignment, the main challenge for internal alignment was how incentives can be defined. The second major challenge was how to measure performance so it could be the basis for giving incentives. The third one was how to analyze the connection between the incentive and [the] wanted performance. The fourth most important challenge, ironically, was the degree of silo thinking that makes it difficult to align incentives. The challenges are mostly similar between supply chain incentive alignment and goal congruence for internal integration. One difference is the difficulty in creating awareness and understanding among employees when it comes to external alignment. This aspect is emphasized for external alignment, whereas internally, the connection to performance measurements is more emphasized.

\section{DISCUSSION, LIMITATIONS, AND PROPOSITIONS}

This study finds that supply chain incentive alignment and the rewards for internal goal congruence are still not developed areas in practice despite being academically discussed for decades (e.g., Cooper et al., 1993; Ellinger et al., 2000; Mentzer et al., 2001; Lee 2004; Narayanan and Raman, 2004; Simatupang and Sridharan, 2005, 2008; Lundin and Norrman, 2010; Fawcett et al., 2015). This research contributes to both academia and practice by empirically exploring and describing the current use of different mechanisms and practices in the industry. Another contribution is the collection of different incentive mechanisms discussed in published research.

The identified gap between how important practitioners perceive supply chain incentive alignment and rewards for internal goal congruence versus current practices also indicates a significant potential to improve SC integration. The practice today is that simple mechanisms, such as price per unit and volume discount (Tsay et al., 1998), are much more commonly used (even for important relationships) than more sophisticated mechanisms. Applying more sophisticated, coordinating mechanisms (Tsay et al., 1998; Cachon, 2003; Narayanan and Raman, 2004; Simatupang and Sridharan, 2005) could enhance risk and reward sharing, as well as drive behavior towards increased SC integration. Even though a few sophisticated mechanisms are used, 
companies generally seem to prefer utilizing sticks rather than carrots. The use of group incentives (Rapp and Torstensson, 1994), for example, is very limited, even though these kinds of coordinating mechanisms work well in certain SC contexts.

The use of more sophisticated and coordinating incentives is slightly more common upstream than downstream. In addition, incentive alignment is only addressed with the first tier of customers or suppliers. We could not find any evidence of incentive alignment in SC in which second-tier suppliers or customers are incorporated. Thus, our study supports the idea that most SCM work in practice is currently focused on dyadic relationships and not on the extended SC.

Regarding cross-functional internal integration (Ellinger et al., 2006; Stank et al., 2011), it is also considered important for inter-organizational external integration (Stevens, 1989; Croxton et al., 2001). Even though silo thinking has been a known problem for decades (e.g., Rummler and Brache, 1991; Spekman et al., 1998; Ellinger, 2000), we still find counterproductive rewards and incongruent goals (Fawcett et al., 2015) in functions, such as sales, marketing, finance, product development, and R\&D. While this might not be entirely surprising, it is more unexpected that many companies have counterproductive incentive structures even in functions within the logistics family. As logisticians claim that they drive process orientation within and between companies, the first step should be to increase the goal congruence between functions. This study confirms the existence of conflicting functional goals, the lack of joint accountability (Ellinger et al., 2006), and the lack of process-oriented rewards (Enz and Lambert, 2015). This research also highlights the link between incongruent goals and internal incentives. This leads to our first proposition:

Proposition I: To close the gap between the perceived importance and actual practice of supply chain incentive alignment, logisticians should reduce internal silo-thinking by creating congruent internal goals within logistics departments and enabling cross-functionality.

To close the gap between perceived importance and actual practice, both practitioners and researchers need to reflect on the major challenges. The second most important challenge in the inter-organizational context, for example, is to create the understanding that missing incentive alignment could create problems. One of Narayanan and Raman's (2004) key steps to address this problem is that companies must first acknowledge that this issue exists. The present study confirms this by reinforcing it as an important aspect.

Similarly, when it comes to the most important challenge for both internal and external alignment, how to define incentives so that they will drive the desired behavior, this issue is known but not addressed in practice. Correspondingly, a key challenge for internal alignment is still (Ellinger et al., 2000; van Hoek and Mitchell, 2006) how to measure performance so that performance measures could be the basis for providing incentives. As we see a lack of implementation and use in practice, as well as limited research on implementation and use, our next propositions are as follows:

Proposition II: The behavior of different misaligned incentives and their effects must be better understood by practitioners in order to close the gap between the perceived importance and actual practice of supply chain incentive alignment.

Proposition III: Knowledge of how to both define and implement sophisticated incentives (that drive wanted behavior) must be developed in order to close the gap between the perceived importance and actual practice of supply chain incentive alignment.

Likewise, the importance of the design of performance metrics and more process-oriented performance measurement systems has been discussed since the 1990s. Neely et al. (1999), for example, raised this issue in his four phases of the performance measurement lifecycle: there is a need to extend focus from the design phase to the phases of implementation, use, and maintenance of the systems. We therefore advocate for more research regarding implementation and use, pioneering practice, barriers, and lessons learned in overcoming implementation barriers. Through this, we also think that this stream of research would increase its practical relevance. Our fourth proposition is as follows:

Proposition IV: Process performance must be better measured, and congruent performance goals must be linked to incentives in order to close the gap between the perceived importance and actual practice of supply chain incentive alignment.

This study has limitations. It is based on an explorative panel study with 48 answers, thus reducing its opportunities to test hypotheses and theory. However, unlike traditional survey studies, a panel approach also has advantages because all the respondents are known, and all are experts in the field. As a result, we believe that we can identify clear patterns and highlight interesting observations. Furthermore, the propositions can be further tested in broader studies. The current geographical limitation to Sweden may have influenced the results based on culture, business practice, and other factors. Conducting global studies that compare the use of incentive alignment and internal rewards in different countries would therefore be interesting. Likewise, a relevant avenue for future research is to obtain a deeper understanding of pioneering practice, for example, related to the use of more sophisticated mechanisms or even group incentives, by using case studies. Group incentives could be studied in the context of CSR; for instance, people issues (e.g., child labor) in the production processes are difficult to observe when suppliers are far away.

Finally, we observed that internal silo thinking was a major challenge for both supply chain incentive alignment and internal goal congruence. A limitation of this study is that it does not fully investigate the interrelation between external and internal integration and the impact of incentives; this is certainly an area where more knowledge and research are needed.

\section{ACKNOWLEDGEMENT}

We would like to thank Dr. Sebastian Pashaei for his input to the article.

\section{REFERENCES}

Agrell, P. J., Lindroth, R., and Norrman, A. (2004). Risk, information, and incentives in telecom supply chains. International Journal of Production Economics 91 (1), pp. 1 $-16$. 
Anupindi, R., and Bassok, Y. (1999). Centralization of stocks: Retailers vs. manufacturer. Management Science 45 (2), pp. $178-191$

Armstrong, J. S., and Overton, T. S. (1977). Estimating nonresponse bias in mail surveys. Journal of Marketing Research 14 (3), pp. 396 - 402.

Bagchi, P. K., and Skjoett-Larsen, T. (2003). Integration of information technology and organizations in a supply chain. International Journal of Logistics Management 14 (1), pp. 89 -108 .

Barratt, M. (2004). Understanding the meaning of collaboration in the supply chain. Supply Chain Management: An International Journal 9 (1), pp. 30 - 42.

Bowersox, D. J, Closs, D. J., and Stank, T. P. (2000). Ten megatrends that will revolutionize supply chain logistics. Journal of Business Logistics 21 (2), pp. 1 - 16.

Brun, A., and Moretto, A. (2012). Contract design and supply chain management in the luxury jewellery industry. International Journal of Retail \& Distribution Management 40 (8), pp. 607 $-628$.

Cachon, G. P. (2003). Suppy chain coordination with contracts. The handbook of operations research and management science, Graves, S., and de Kok, T. (Eds), Kluwer, Amsterdam, pp. $227-339$.

Cachon, G. P., and Lariviere, M. A. (2001). Contracting to assure supply: How to share demand forecasts in a supply chain. Management Science 47 (5), pp. 629 - 646.

Cachon, G. P., and Lariviere M. A. (2005). Supply chain coordination with revenue-sharing contracts: Strengths and limitations. Management Science 51 (1), pp. 30 - 44.

Cook, L. S., Heiser, D. R., and Sengupta, K. (2011). The moderating effect of supply chain role on the relationship between supply chain practices and performance: An empirical analysis. International Journal of Physical Distribution \& Logistics Management 41 (2), pp. 104 - 134.

Cooper, M. C., and Ellram, L. M. (1993). The relationship between supply chain management and keiretsu. International Journal of Logistics Management 4 (1), pp. 1 - 12.

Cooper, M. C., Lambert, D. M., and Pagh, J. D. (1997). Supply chain management - more than a new name for logistics. International Journal of Logistics Management 8 (1), pp. 1 14

Croxton, K. L., García-Dastugue, J., Lambert, D. M., and Rogers, D. S. (2001). The supply chain management processes. International Journal of Logistics Management 12 (2), pp. 13 $-36$.

Cusumano, M. A., and Takeishi, A. (1991). Supplier relations and management: A survey of Japanese, Japanese-transplant, and US auto plants. Strategic Management Journal 12 (8), pp. $563-588$

Dana, J., and Spier, K. (2001). Revenue sharing and vertical control in the video rental industry. The Journal of Industrial Economics 49 (3), pp. 223 - 245.

Danese, P., Romano, P., and Formentini, M. (2013). The impact of supply chain integration on responsiveness: The moderating effect of using an international supplier network. Transportation Research Part E 49 (1), pp. 125 - 140.

deSouza, A., and Haddud, A. (2017). Supply chain management integration in maintenance and repair services. Operations and Supply Chain Management 10 (4), pp. 200 - 213.

Eisenhardt, K. M. (1989). Agency theory: An assessment and review. Academy of Management Review 14 (1), pp. 57 - 74.

Ellinger, A. E. (2000). Improving marketing/logistics crossfunctional collaboration in the supply chain. Industrial Marketing Management 29 (1), pp. 85 - 96.

Ellinger, A. E., Keller, S. B., and Hansen, J. D. (2006). Bridging the divide between logistics and marketing: Facilitating collaborative behavior. Journal of Business Logistics 27 (2), pp. $1-27$.
Eng-Larsson, F., and Norrman, A. (2014). Modal shift for greener logistics - exploring the role of the contract. International Journal of Physical Distribution \& Logistics Management 44 (10), pp. $721-743$.

Enz, M. G., and Lambert, D. M. (2012). Using cross-functional, cross-firm teams to co-create value: The role of financial measures. Industrial Marketing Management 41 (1), pp. 495 $-507$.

Enz, M. G., and Lambert, D. M. (2015). Measuring the financial benefits of cross-functional integration influences management's behaviour. Journal of Business Logistics 36 (1), pp. $25-48$.

Fawcett, S. E., Jin, Y. H., Fawcett, A. M., and Magnan, G., (2017). I know it when I see it: The nature of trust, trustworthiness signals, and strategic trust construction. The International Journal of Logistics Management 28 (4), pp. 914 - 938.

Fawcett, S. E., and Magnan, G. M. (2002). The rhetoric and the reality of supply chain integration. International Journal of Physical Distribution \& Logistics Management 32 (6), pp. $339-361$.

Fawcett, S. E., McCarter, M. W., Fawcett, A. M., and Magnan, S. W. G. (2015). Why supply chain collaboration fails: The socio-structural view of resistance to relational strategies. Supply Chain Management: An International Journal 20 (6), pp. $648-663$.

Forza, C. (2002). Survey research in operations management: A process-based perspective. International Journal of Operations \& Production Management 22 (2), pp. 152 - 194.

Fugate, B., Sahlin, F., and Menzter, J. T. (2006). Supply chain management coordination mechanisms. Journal of Business Logistics 27 (5), pp. $129-162$.

Giménez, C., and Ventura, E. (2005). Logistics-production, logistics-marketing and external integration - their impact on performance, International Journal of Operations and Production Management 25 (1), pp. 20 - 38.

Grubic, T., Bastl, M., Fan, I-S., Harrison, A., and Templar, S. (2010). Towards the integrative supply chain model. International Journal of Logistics: Research and Applications 13 (1), pp. $59-73$.

Gunasekaran, A. (2004). Supply chain management: Theory and applications. European Journal of Operational Research 159 (2), pp. $265-268$

Halldórsson, Á., Larson, P. D., and Poist, R. F. (2008). Supply chain management: A comparison of Scandinavian and American perspectives. International Journal of Physical Distribution \& Logistics Management 38 (2), pp. 126 - 142.

Hezarkhani, B., and Kubiak, W. (2010). Coordinating contracts in SCM: A review of methods and literature. Decision Making in Manufacturing and Services 4 (1-2), pp. 5-28.

Hulthén, H., Naslund, D., and Norrman, A. (2017). Challenges of measuring performance of the sales and operations planning process. Operations and Supply Chain Management 10 (1), pp. $4-16$.

Hübner, A., Wollenburg, J., and Holzapfel, A. (2016). Retail logistics in the transition from multi-channel to omnichannel. International Journal of Physical Distribution and Logistics Management 46 (6/7), pp. 562 - 583.

Jensen, M., and Meckling. W. (1976). Theory of the firm: Managerial behaviour, agency cost and ownership structure. Journal of Financial Economics 3 (4), pp. 305 - 360.

Lambert, D. M., Garcia-Dastugue, S. J., and Croxton, K. L. (2005). An evaluation of process-oriented supply chain management frameworks. Journal of Business Logistics 26 (1), pp. 25 - 52.

Lariviere, M., and Porteus, E. (2001). Selling to the newsvendor: An analysis of price-only contracts. Manufacturing and Service Operations Management 3 (4), pp. 293 - 305.

Lee, H. L. (2004). The triple-A-supply chain. Harvard Business Review 82 (10), pp. $102-112$. 
Lee H. L., Padmanabhan, V., and Wang, S. (1997). The bullwhip effect in supply chains. Sloan Management Review 38 (3), pp. $93-102$.

Lee, H. L., and Whang, S. (1999). Decentralized multi-echlon supply chains: Incentives and information. Management Science 45 (5), pp. $633-640$.

Leng, M., and Zhu, A. (2009). Side-payment contracts in twoperson nonzero-sum supply chain games: Review, discussion and applications. European Journal of Operational Research 169 (2), pp. $600-618$.

Liang, L., and Atkins, D. (2013). Designing service level agreements for inventory management. Production and Operations Management 22 (5), pp. 1103 - 1117.

Lundin, J. F., and Norrman, A. (2010). The misalignment cycle: Is the management of your supply chain aligned? International Journal of Physical Distribution \& Logistics Management 40 (4), pp. $277-297$.

Mentzer, J. T., DeWitt, W., Keebler, J. S., Soonhong Min, Nix, N. W., Smith, C. D., and Zacharia, Z. (2001). Defining supply chain management. Journal of Business Logistics 22 (2), pp. $1-26$.

Min, S., and Mentzer, J. T. (2000). The role of marketing in supply chain management. International Journal of Physical Distribution \& Logistics Management 30 (9), pp. $765-787$.

Motwani, J., Larson, L., and Ahuja, S. (1998). Managing a global supply chain partnership. Logistics Information Management 11 (6), pp. $349-54$.

Msimangira, K., and Venkatraman, S. (2014). Supply chain management integration: Critical problems and solutions. Operations and Supply Chain Management 7 (1), pp. 23 - 31.

Nandi, S. (2016). Dynamics of coordination for return policy contracts with warranty. Operations and Supply Chain Management 9 (2), pp. 105 - 118.

Narasimhan, R., and Kim, S. W. (2001). Information system utilization strategy for supply chain integration. Journal of Business Logistics 22 (2), pp. 51 - 75.

Narayanan, V. G., and Raman, A. (2004). Aligning incentives in supply chains. Harvard Business Review 82 (11), pp. $94-$ 102.

Naslund, D., and Hulten, H. (2012). Supply chain management integration: A critical analysis. Benchmarking: An International Journal 19 (4/5), pp. 481 - 501.

Neely, A. (1999). The performance measurement revolution: Why now and what next? International Journal of Operations \& Production Management 19 (2), pp. 205 - 228

Norrman, A. (2008). Supply chain risk-sharing contracts from a buyers' perspective: Content and experiences. International Journal of Procurement Management 1 (4), pp. 371 - 393.

Ouchi, W. G. (1979). A conceptual framework for design of organizational control mechanisms. Management Science 25 (9), pp. $833-848$.

Pagell, M. (2004). Understanding the factors that enable and inhibit the integration of operations, purchasing and logistics. Journal of Operations Management 22 (5), pp. 459 - 487.

Piercy, N., and Ellinger, A. (2015). Demand- and supply-side crossfunctional relationships: An application of disconfirmation theory. Journal of Strategic Marketing 23 (1), pp. 49 - 71.

Porter, M. G. (2019). Supply chain integration: Does organizational culture matter? Operations and Supply Chain Management 12 (1), pp. $49-59$.

Ralston, P. M., Blackhurst, J., Cantor, D. E. and Crum, M. R. (2015). A structure-conduct-performance perspective of how strategic supply chain integration affects firm performance. Journal of Supply Chain Management 51 (2), pp. 47 - 64.

Rapp B., and Thorstensson A. (1994), Vem skall ta risken? Studentlitteratur, Lund

Richey, R. G., Roath, A. S., Whipple, J. M., and Fawcett, and S. E. (2010). Exploring a governance theory of supply chain management: Barriers and facilitators to integration. Journal of Business Logistics 31 (1), pp. 237 - 256.

Rodriquez, A., Stank, T., and Lynch, D. (2004). Linking strategy, structure, process, and performance in integrated logistics. Journal of Business Logistics 25 (2), pp. 65 - 94.

Rummler, G. A., and Brache, A. P. (1991). Managing the white space. Training 28 (1), pp. $55-70$.

Schoenherr, T., and Swink, M. (2012). Revisiting the arcs of integration: Cross-validations and extensions. Journal of Operations Management 30 (1-2), pp. 99 - 115.

Selviaridis, K., and Norrman, A. (2015). Performance-based contracting for advanced logistics services: Challenges in its adoption, design and management. International Journal of Physical Distribution \& Logistics Management 45 (6), pp. $592-617$.

Simatupang, T. M., and Sridharan, R. (2005). Supply chain discontent. Business Process Management Journal 11 (4), pp. $349-369$.

Simatupang, T. M., and Sridharan, R. (2008). Design for supply chain collaboration. Business Process Management Journal 14 (3), pp. $401-418$.

Spekman, R. E., Kamauff Jr., J. W., and Myhr, N. (1998). An empirical investigation into supply chain management: A perspective on partnership. International Journal of Physical Distribution \& Logistics Management 28 (8), pp. $630-650$.

Stank, T. P., Dittmann, J. P., and Autry, Ch. W. (2011). The new supply chain agenda: A synopsis and directions for future research. International Journal of Physical Distribution and Logistics Management 41 (10), pp. 940 - 955.

Stank, T. P., Keller, S. B., and Daugherty, P. B. (2001). Supply chain collaboration and logistical service performance. Journal of Business Logistics 22 (1), pp. 29 - 48.

Stevens, G. C. (1989). Integrating the supply chain. International Journal of Physical Distribution \& Materials Management 19 (3), pp. $3-8$.

Stevens, G. C., and Johnson, M. (2016). Integration the supply chain ... 25 years on. International Journal of Physical Distribution \& Logistics Management 46 (1), pp. 19 - 42.

Ståhl Elvander, M., Sarpola, S., and Mattsson, S-A. (2007). Framework for characterizing the design of VMI systems. International Journal of Physical Distribution \& Logistics Management 37 (10), pp. $782-798$.

Trkman, P., Stemberger, M. I., Jaklic, J., and Groznik, A. (2007). Process approach to supply chain integration. Supply Chain Management: An International Journal 12 (2), pp. $116-128$.

Tsay, A. (1999). Quantity-flexibility contract and suppliercustomer incentives. Management Science 45 (10), pp. 1339 $-1358$.

Tsay, A., Nahmias, A. S., and Agrawal, N., 1998. Modelling supply chain contracts: A review. Chapter 10. Quantitative models for supply chain management, Tayur, S., Ganeshan, R., and Magazine, M. (Eds.), Kluwer Academic Publishers, Dordrecht.

van Hoek, R., Ellinger, A. E., and Johnson, M. (2008). Great divides: Internal alignment between logistics and peer functions. The International Journal of Logistics Management 19 (2), pp. $110-129$.

Van Hoek, R., and Mitchell. A. J. (2006). The challenge of internal misalignment. International Journal of Logistics 9 (3), pp. $269-281$.

Van Hoek, R., and Weken, H. A. M. (2000), Smart (Car) and Smart Logistics, Council for Logistics Management, Oak Brook, IL.

Wong, Ch. Y., Sakun, Boon-itt, and Wong, Ch., W. Y. (2011). The contingency effects of environmental uncertainty on the relationship between supply chain integration and operational performance. Journal of Operations Management 29 (6), pp. $604-615$ 


\section{APPENDIX A}

Table 2 Comparison of the degree to which different contract mechanisms are used (versus price per unit). (7-point Likert scale, $1=$ used to a very low degree/not at all, and $7=$ used to a very high degree)

\section{Paired Samples Test}

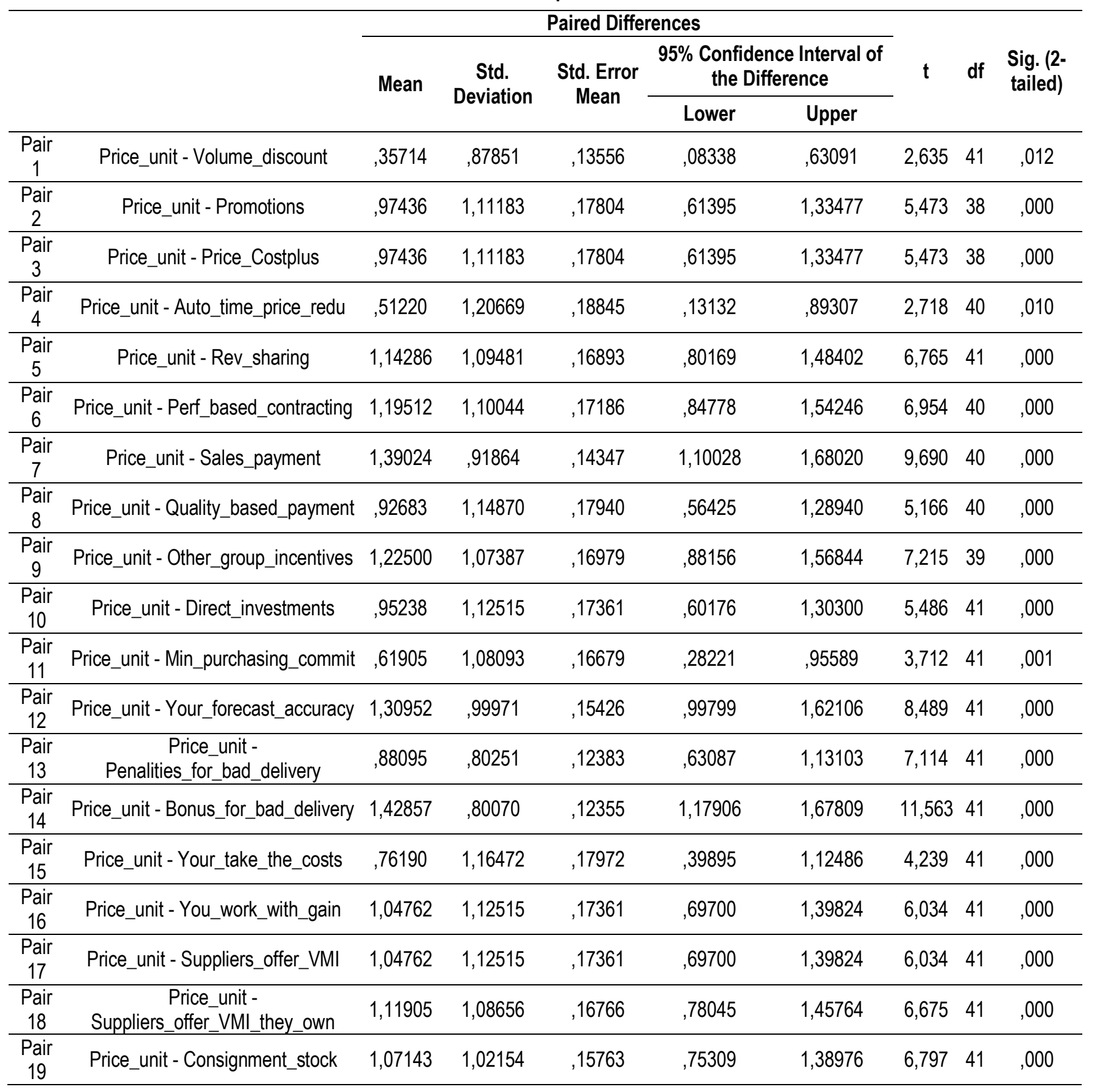




\section{APPENDIX B}

Table 3 Comparison of the degree to which different contract mechanisms are used (versus volume discount). (7-point Likert scale, 1=used to a very low degree/not at all, and $7=$ used to a very high degree)

\section{Paired Samples Test}

\begin{tabular}{|c|c|c|c|c|c|c|c|c|c|}
\hline & & \multicolumn{4}{|c|}{ Paired Differences } & $\mathbf{t}$ & \multicolumn{2}{|l|}{ df } & \multirow[t]{3}{*}{$\begin{array}{l}\text { Sig. (2- } \\
\text { tailed) }\end{array}$} \\
\hline & & \multirow[t]{2}{*}{ Mean } & \multirow[t]{2}{*}{$\begin{array}{l}\text { Std. } \\
\text { Deviation }\end{array}$} & \multirow[t]{2}{*}{$\begin{array}{l}\text { Std. } \\
\text { Error } \\
\text { Mean }\end{array}$} & \multicolumn{2}{|c|}{$\begin{array}{l}95 \% \text { Confidence } \\
\text { Interval of the } \\
\text { Difference }\end{array}$} & & & \\
\hline & & & & & Lower & Upper & & & \\
\hline Pair 1 & Volume_discount - Price_unit &,- 35714 & 87851 & ,13556 &,- 63091 &,- 08338 & $-2,635$ & 41 & 012 \\
\hline Pair 2 & Volume_discount - Promotions & ,61538 & 87706 &, 14044 & ,33108 & ,89969 & 4,382 & 38 &, 000 \\
\hline Pair 3 & Volume_discount - Price_Costplus & ,61538 & ,87706 & ,14044 & ,33108 & ,89969 & 4,382 & 38 &, 000 \\
\hline Pair 4 & Volume_discount - Auto_time_price_redu & ,14634 & 1,06210 & ,16587 &,- 18890 & ,48158 & ,882 & 40 &, 383 \\
\hline Pair 5 & Volume_discount - Rev_sharing & ,78571 & 1,02495 & , 15815 & ,46632 & 1,10511 & 4,968 & 41 &, 000 \\
\hline Pair 6 & Volume_discount - Perf_based_contracting & 82927 & 1,07010 & , 16712 & ,49150 & 1,16703 & 4,962 & 40 &, 000 \\
\hline Pair 7 & Volume_discount - Sales_payment & 1,02439 & ,90796 & ,14180 & ,73780 & 1,31098 & 7,224 & 40 &, 000 \\
\hline Pair 8 & Volume_discount - Quality_based_payment &, 56098 & 1,07352 & , 16766 & ,22213 & ,89982 & 3,346 & 40 &, 002 \\
\hline Pair 9 & Volume_discount - Other_group_incentives & ,87500 & 1,11373 & , 17610 &, 51881 & 1,23119 & 4,969 & 39 &, 000 \\
\hline Pair 10 & Volume_discount - Direct_investments &, 59524 & 1,06059 & , 16365 & ,26473 &, 92574 & 3,637 & 41 &, 001 \\
\hline Pair 11 & Volume_discount - Min_purchasing_commit & ,26190 & 1,12747 &, 17397 &,- 08944 &, 61325 & 1,505 & 41 &, 140 \\
\hline Pair 12 & Volume_discount - Your_forecast_accuracy & ,95238 & ,90937 & , 14032 & 66900 & 1,23576 & 6,787 & 41 &, 000 \\
\hline Pair 13 & $\begin{array}{c}\text { Volume_discount - } \\
\text { Penalities_for_bad_delivery }\end{array}$ &, 52381 & 91700 & , 14150 & ,23805 & ,80957 & 3,702 & 41 & ,001 \\
\hline Pair 14 & Volume_discount - Bonus_for_bad_delivery & 1,07143 & ,77752 & 11997 & ,82914 & 1,31372 & 8,931 & 41 &, 000 \\
\hline Pair 15 & Volume_discount - Your_take_the_costs & ,40476 & 1,19060 & ,18371 & 03374 & ,77578 & 2,203 & 41 & ,033 \\
\hline Pair 16 & Volume_discount - You_work_with_gain & 69048 & 1,11504 &, 17205 & 34300 & 1,03795 & 4,013 & 41 &, 000 \\
\hline Pair 17 & Volume_discount - Suppliers_offer_VMI & 69048 & 99971 & ,15426 & ,37894 & 1,00201 & 4,476 & 41 &, 000 \\
\hline Pair 18 & $\begin{array}{c}\text { Volume_discount } \\
\text { Suppliers_offer_VMI_they_own }\end{array}$ & ,76190 & ,90553 & 13973 & ,47972 & 1,04409 & 5,453 & 41 &, 000 \\
\hline Pair 19 & Volume_discount - Consignment_stock & ,71429 & ,99476 &, 15349 & ,40430 & 1,02427 & 4,653 & 41 &, 000 \\
\hline
\end{tabular}

Andreas Norrman is Professor in Supply Chain Structure and organization at Lund University, Faculty of Engineering, Sweden. He has a Ph.D. in Logistics from Linköping University, Sweden. Andreas has worked as a management consultant at A.T. Kearney with Supply Chain Management and sourcing issues. His research interests include supply chain incentive alignment, supply chain risk management, omni-channel warehousing, and change management. He publishes in leading journal and he received multiple Emerald Highly Commended Awards for his work with IJPD\&LM, both as author and reviewer. At Lund University he has been awarded Excellent Teaching Practice.

Dag Näslund is the Richard de Raismes Kip Professor of Process and Operations Management at the University of North Florida's Coggin College of Business. Dag also holds a position at Lund University in Sweden. Dag received his Ph.D. in Process and Supply Chain Management from Lund University in Sweden. His research interests include organizational change efforts, performance measurements, information sharing and integration in supply chains and research methodology. Dag has won several prestigious journal and conference awards. He is also active in the business world leading workshops and presenting at industry seminars/conferences both in the US and internationally. 